26

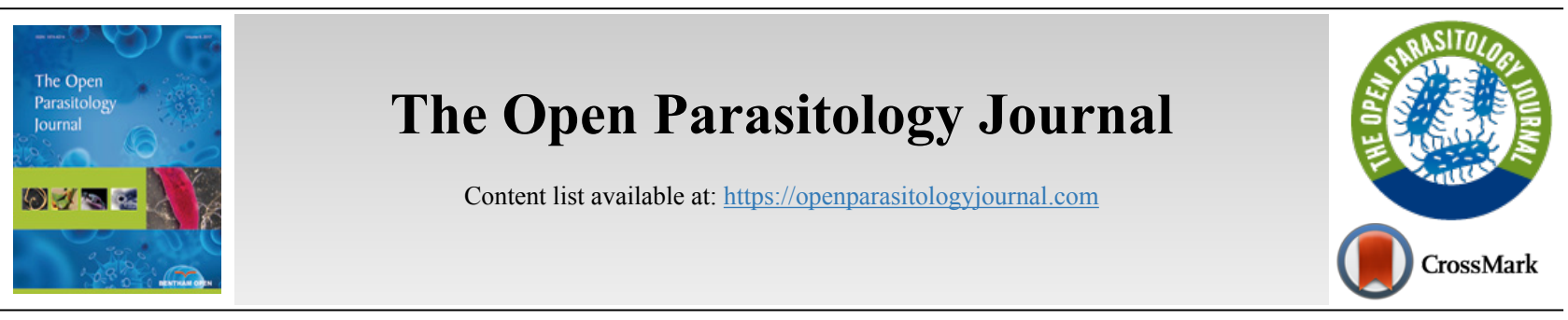

RESEARCH ARTICLE

\title{
Ultrastructure-based Insights on Anti-Trichomonas vaginalis Effects of Selected Egyptian Red Sea Marine Resources
}

\author{
G.M. Tawfeek, H.S. Elwakil and R.M. Sarhan ${ }^{*}$ \\ Department of Medical Parasitology, Faculty of Medicine, Ain Shams University, Cairo, Egypt
}

\begin{abstract}
:
Background:

Metronidazole is used for the treatment of trichomoniasis. However, a growing number of Trichomonas vaginalis (T. vaginalis) isolates are now resistant, which is an urgent issue to search for new alternatives. Worldwide marine pharmacy confirms the enormous potential of sea species as a source of novel pharmaceuticals.

Objective:

This study aimed to investigate the anti-T. vaginalis activities of ethanolic extracts of Red Sea marine resources, soft corals; Sarcophyton glaucum and Litophyton arboreum and methanolic extracts of Red Sea brown algae; Liagora farinosa, Colpomenia sinuosa, Hydroclathrus clathratus, and Sargassum graminifolium, as well as sea cucumber (Holothuria fuscocinerea) and sea urchin (Echinometra mathaei). T. vaginalis growth inhibition was determined using 2 concentrations for each marine extract 10 and $100 \mu \mathrm{g} / \mathrm{ml}$ in comparison to media control. Drugs that showed good initial activity were further tested to calculate their IC50 in comparison to metronidazole. The ultrastructural impact of the more effective extracts was further assessed.

Results:

H. clathratus, L. farinose, sea urchin $E$. mathaei and sea cucumber $H$. fuscocinerea reduced the growth of $T$. vaginalis effectively and showed high activity with IC50 of $0.985 \pm 0.08,0.949 \pm 0.04,0.845 \pm 0.09$ and $0.798 \pm \mu \mathrm{g} / \mathrm{ml} \pm \mathrm{SD}$, respectively. Concerning microscopic analysis, marine extract and metronidazole-treated cells presented similar morphological changes. The nuclear membrane was damaged, the nuclei were dissolved, the rough endoplasmic reticulum was widened, and the chromatin was accumulated. In the cytoplasm, numerous autophagic vacuoles appeared, the organelles were disintegrated, the flagella were internalized and hydrogenosomes with altered morphologies were observed. The cell membrane was partially damaged, with cytoplasmic leakage and cell disintegration.
\end{abstract}

Conclusion:

This study describes the report on the activity and morphological changes induced by Egyptian Red Sea marine resources against $T$. vaginalis. The results obtained herein presented new opportunitiess. Further, bio-guided fractionation and isolation of active compounds are needed.

Keywords: Trichomonas vaginalis, Red sea, Marine resources, Soft corals, Red and brown algae, Sea cucumber, Sea urchin, Ultrastructure.

\section{Article History}

Received: November 20, 2018

Revised: January 07, 2019

Accepted: January 23, 2019

\section{INTRODUCTION}

Trichomoniasis, caused by the flagellate protozoan Trichomonas vaginalis ( $T$. vaginalis), is the most common sexually transmitted disease in the world with the highest rate of incidence, 276 million new cases yearly [1]. Although curable, it may cause severe health consequences especially in females such as infertility, human immunodeficiency virus acquisition,

\footnotetext{
* Address correspondence to this author at the Department of Medical Parasitology, Faculty of Medicine, Ain Shams University, Cairo, Egypt; E-mail: raniasarhan99@gmail.com
}

cervical cancer and adverse pregnancy outcomes leading to premature rupture of placental membranes, premature labor and low-birth-weight [2]. Though generally asymptomatic in men, yet its association to cancer prostate is alarming [3].

Metronidazole, the drug of choice has shown clinical resistance as early as in 1962 [4]. It is estimated that approximately $2.5-10 \%$ of all cases display resistance. Because of the lack of approved alternative treatments, those resistant cases are therefore usually treated with increased doses, which may lead to side effects $[5,6]$. These side effects may result in 
treatment discontinuation, leading to further spread of infection and emergence of more resistant strains [7]; therefore novel therapeutic alternatives for the treatment of trichomoniasis are crucial [8].

Marine resources, through evolution, had to develop characteristics to cope with the changes in the environment, namely extreme conditions of temperature, pressure, and exposure to high concentrations of pathogenic bacteria, fungi, and viruses. Many of these adaptations resulted in the production of compounds that revealed interesting activities in the pharmacological field of cancer, acquired immune deficiency syndrome and arthritis [9].

Seventy-five marine compounds were reported to have antidiabetic, anti-inflammatory activities and affect the immune and nervous system. In fact, several marine compounds were approved by the Food and Drug Administration and are currently available to the public as drugs for leukemia, metastatic breast cancer, and Hodgkin's disease [10].

Several research groups around the world have paid attention to discover natural products from marine organisms with activity against protozoal diseases, such as malaria, Chagas disease, leishmaniasis, and African trypanosomosis [11 - 13]. Anti-Trichomonas activity was also described in studies on marine algae [14 - 16] and fungi [17]. Extracts from twenty-five seaweeds were tested against $T$. vaginalis, of which $44 \%$ presented high to moderate activity with low cytotoxicity [14].

The Red Sea is a hot spot for marine biodiversity. Approximately $40 \%$ of the marine species identified worldwide are native to the Red Sea [18].

In recent years, a number of studies have proved that the bioactive compounds isolated from Red Sea marine organisms exhibited pesticidal [19], anti-oxidant [20], antimicrobial and anti-inflammatory properties [21,22]. The research on natural products, isolated from Red Sea marine extracts, with antiparasitic activity is very limited [23, 24] although these products may be a suitable alternative to synthetic drugs in the future as they are relatively safe, biodegradable, and are easily available [25].

Given the need for anti-Trichomonas novel therapies and the emerging importance of marine-associated extracts as a source of bioactive molecules, this study aimed to shed light on the activity of eight Egyptian Red Sea marine resources; ethanolic extracts of two soft corals; Sarcophyton glaucum (Quoy and Gaimard, 1833) and Litophyton arboreum (Forskal, 1775) and methanolic extracts of four red and brown algae; Liagora farinose (Lamouroux, 1816), Colpomenia sinuosa (Derbès and Solier, 1851), Hydroclathrus clathratus (Howe, 1920) and Sargassum graminifolium (Agardh, 1820) as well as sea cucumber; Holothuria fuscocinerea (Jaeger, 1833) and sea urchin; Echinometra mathaei (Blainville, 1825) on T. vaginalis growth. Ultrastructural analysis was employed to clarify their effect.

\section{MATERIALS AND METHODS}

This study was conducted at the Parasitology Research and Diagnostic Laboratory unit, Parasitology Department, Faculty of Medicine, Ain Shams University, Egypt, from May 2016 to March 2018.

\subsection{The Marine Extracts}

The marine resources were kindly provided by Professor Dr. Hans-Georg Breitinger, Head of Biochemistry Department at the German University in Cairo,Egypt. They were collected and identified from the Red Sea intertidal zone of Hurghada coast.

$50 \mathrm{~g}$ of each marine soft coral extracts were macerated in $100 \mathrm{ml}$ of $70 \%$ aqueous ethanol and then maneuvered [26]. The red and brown algae were rinsed with sterile water to remove any associated debris then kept in shade for a week. Lyophilized samples $(15 \mathrm{~g})$ were macerated in $100 \mathrm{ml}$ of dichloromethane: methanol (7:3) for a whole day at room temperature and then the extract was prepared [14]. The sea cucumber (H. fuscocinerea), was freshly harvested and rinsed with distilled water to remove debris. Its body wall was cut into pieces and dried at room temperature in dim light before being ground to a fine powder. Pieces of the body wall were macerated in $300 \mathrm{ml}$ of methanol-water (50:50) and the extract was prepared [27]. The sea urchin extract was prepared from live specimens (E. mathaei) and their dissected ovaries were preserved in $100 \%$ methanol [28]. All the prepared extracts were stored in dark bottles at $4{ }^{\circ} \mathrm{C}$ until used.

\subsection{The Culture of $T$. Vaginalis}

Motile trophozoites were isolated, pooled and examined microscopically from vaginal washouts of patients attending the outpatient clinic, Gynecology and Obstetrics Hospital, Ain Shams University [29]. Trichomonads were in vitro cultured. Organisms exhibiting motility and normal morphology during the logarithmic growth phase were collected, centrifuged, washed three times with phosphate-buffered saline (PBS) 1x $(\mathrm{pH} 7)$, and resuspended in a new medium then sub-cultured every $48 \mathrm{~h}$ [30].

\subsection{In vitro Susceptibility Assays}

For the initial screen of the activity of the marine extracts, they were dissolved in $1 \mathrm{ml}$ of dimethylsulfoxide (DMSO) and added to microtubes containing $1.5 \mathrm{ml}$ of medium to reach concentrations of 10 and $100 \mu \mathrm{g} / \mathrm{ml}$ for each extract. The solutions were inoculated with $T$. vaginalis to obtain $4 \times 10^{4}$ trophozoites $/ \mathrm{ml}$ and then were incubated for 2 days at $37^{\circ} \mathrm{C}$. In the tubes of control cultures, the extracts were replaced by water. After incubation, viable cells were identified and counted microscopically using a hemocytometer based on the morphology and motility and trypan blue dye exclusion where samples were mixed with trypan blue $(0.2 \%)$ in equal volumes. Results were expressed as the percentage of living organisms compared to controls and marine extracts that resulted in the same growth inhibition percentage at the two concentrations were excluded from the secondary screening [31].

In the secondary screening, the selected marine extracts at concentrations of $3.1,10,31.6,100$, and $316.2 \mu \mathrm{g} / \mathrm{ml}$ were tested in duplicates to determine their $50 \%$ inhibitory concentration (IC50) in which $50 \%$ of $T$. vaginalis cells were alive and $50 \%$ were dead [32]. Culture and readout were carried out 


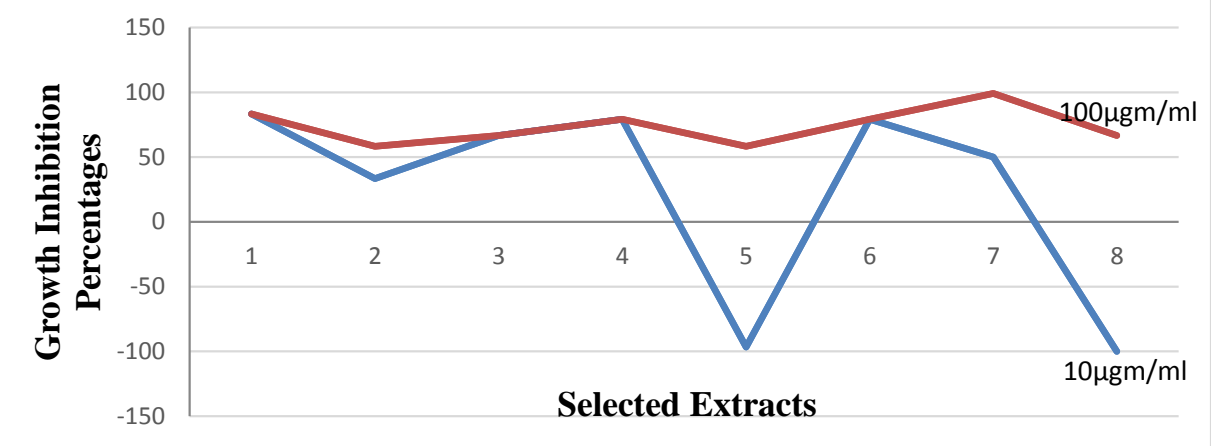

Fig. (1). Screening of the growth inhibition percentage of the 8 extracts at the two concentrations 10 and $100 \mu \mathrm{g} / \mathrm{ml}$. Data represent mean \pm standard deviation, all in duplicates. Sarcophyton glaucum (1), Liagora farinosa (2), Litophyton arboretum (3), Colpomenia sinuosa (4), Hydroclathrus clathratus (5), Sargassum graminifolium (6) and extracts Holothuria fuscocinerea (7) and sea urchin Echinometra mathaei (8).

as described in the first round of screening. Each test included metronidazole $(1 \mu \mathrm{g} / \mathrm{ml})$ as a positive control, a solvent control (culture medium plus trophozoites and DMSO), and negative control (culture medium plus trophozoites). The IC50 was calculated for each treatment using probit analysis (Graph Pad Prism 4 software). The trophozoites in each tube were subcultured in a new medium for another 2 days, without antiprotozoal drugs or extracts. Trophozoites treated with the selected extracts from the second screening were subjected to the ultrastructural study.

\subsection{Transmission Electron Microscopy (TEM)}

Untreated and treated trophozoites with the selected marine extracts as well as metronidazole were sequentially fixed for $1 \mathrm{~h}$ at room temperature in a (v/v) solution containing $2.5 \%$ glutaraldehyde and cacodylate buffer (0.1), pH 7.2. Fixed samples were washed twice in PBS and fixed with $1 \%(\mathrm{v} / \mathrm{v})$ osmium tetroxide in $0.1 \mathrm{M}$ cacodylate buffer for half an hour, $\mathrm{pH} \mathrm{7.2,} \mathrm{at} \mathrm{room} \mathrm{temperature} \mathrm{and} \mathrm{dehydrated} \mathrm{in} \mathrm{increasing}$ concentrations of ethanol, followed by final dehydration in $100 \%$ propylene oxide. Samples were embedded in Epon 812. Thin sections were cut and processed [31]. An average of 40-50 fields of each preparation was examined.

\section{RESULTS}

The primary screening showed an inhibited growth of $T$. vaginalis in vitro in different extents. Of the eight tested marine extracts, S. glaucum, L. arboreum, C. sinuosa, and $S$. graminifolium showed the same growth inhibition percentage at the two concentrations 10 and $100 \mu \mathrm{g} / \mathrm{ml}$ and were excluded from the second screening (Fig. 1).

The IC50 from H. clathratus, L. farinose, E. mathaei and $H$. fuscocinerea were; $0.985 \pm 0.08,0.949 \pm 0.04,0.845 \pm 0.09$ and $0.798 \pm 0.10 \mu \mathrm{g} / \mathrm{ml} \pm \mathrm{SD}$, respectively. Due to the lack of data on anti-trichomal activity scores from marine resources extracts, we define high activity as IC50 $\leq 5 \mu \mathrm{g} / \mathrm{ml}$, moderate activity as IC50 $5.1-10 \mu \mathrm{g} / \mathrm{ml}$ and low activity as IC50 $>10 \mu \mathrm{g} / \mathrm{ml}$ [14]. The results revealed high anti-trichomonal activity from the tested marine extracts. None of the extracts assayed were more active than metronidazole (IC50; $0.04 \mu \mathrm{g} / \mathrm{ml} \pm \mathrm{SD}$ ).

Fig. (2) represented the light microscopy of $T$. vaginalis trophozoites treated with $100 \mu \mathrm{g} / \mathrm{ml}$ of E. mathaei. Parasites were stained with trypan blue dye. Viable parasites appeared unstained while non-viable parasites appeared stained. The TEM fine structure of $T$. vaginalis can be seen in Fig.(3) representing the trophozoites without any treatment (negative control), Figs. (4-7) showed the trophozoites incubated in $L$. farinosa, H. clathratus, H. fuscocinerea, and E. mathaei, respectively and Fig. (8) represented the trophozoites incubated in metronidazole (positive control).

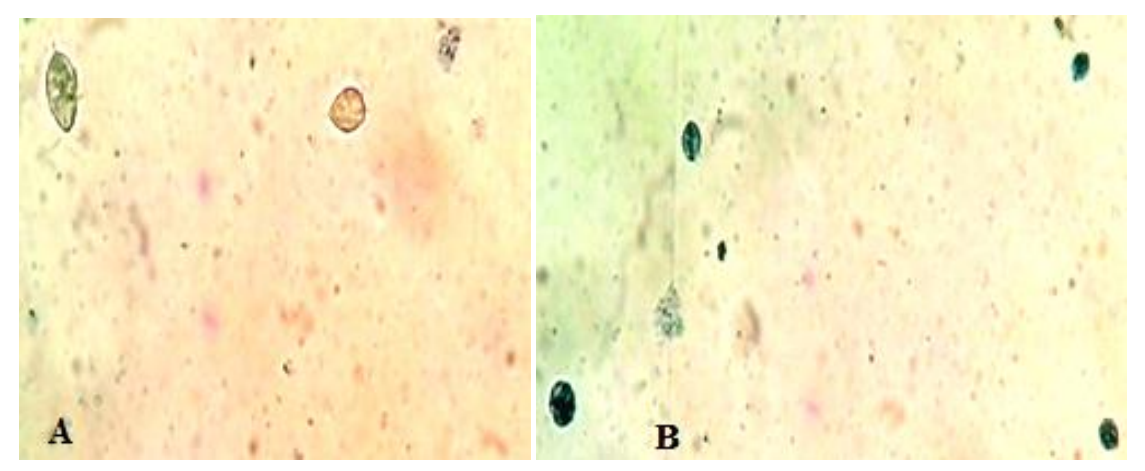

Fig. (2). Light microscopy of T. vaginalis trophozoites (x40) treated with $100 \mathrm{ug} / \mathrm{mL}$ of sea urchin (Echinometra mathaei). Parasites were stained with trypan blue dye. (A) unstained viable parasites of untreated control, (B) stained non-viable parasites treated with sea urchin. 


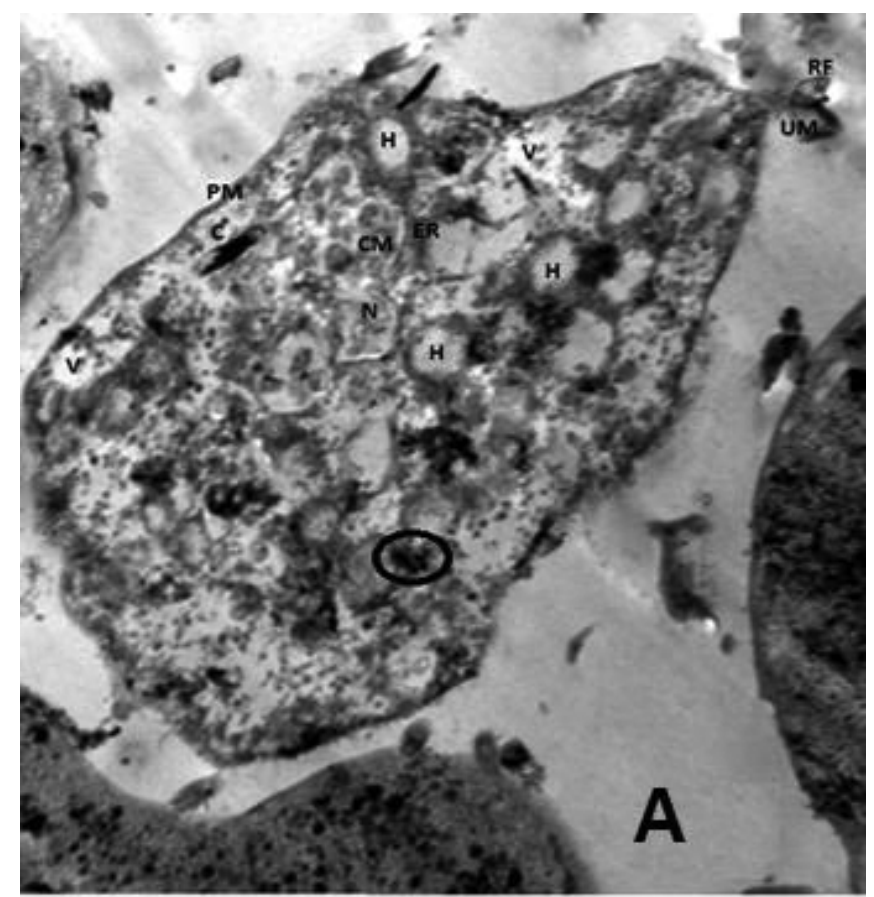

$\overline{500} \mathrm{~nm}$

TEM Mag $=15000 x$

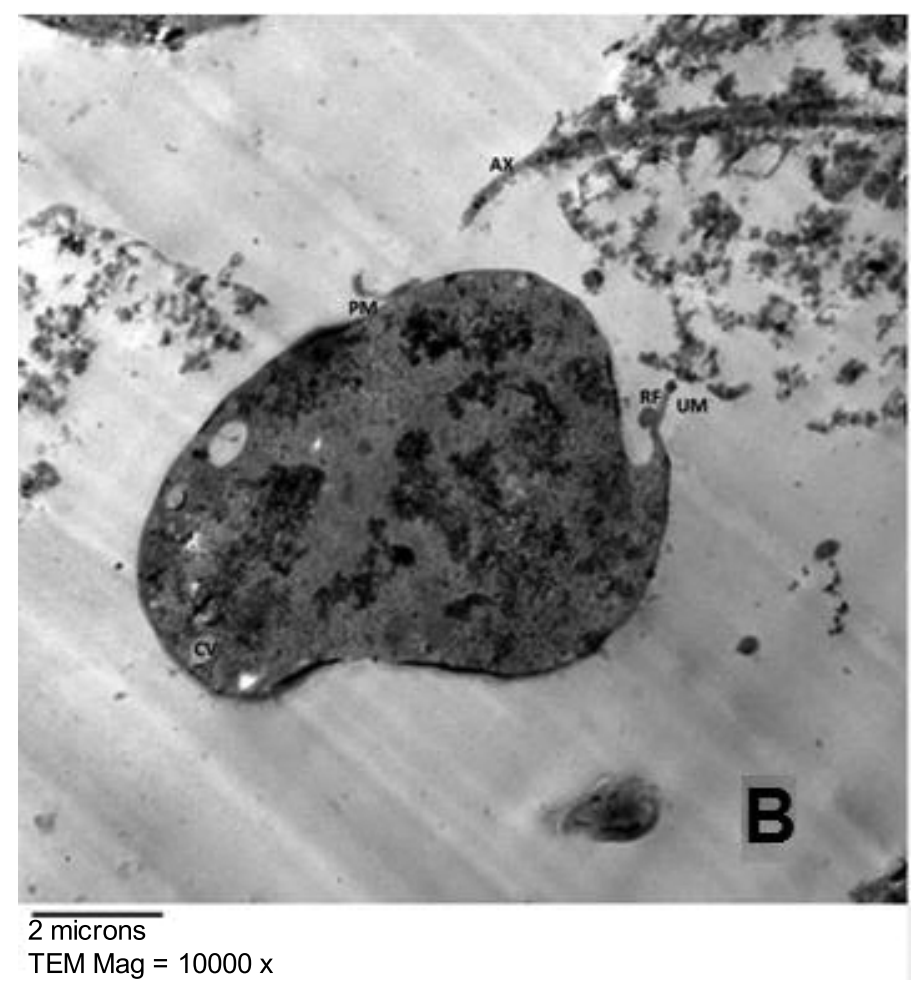

Fig. (3). Transmission electron micrographs of untreated T. vaginalis were shown in with the plasma membrane (PM), the undulating membrane (UM) and its recurrent flagellum (RF) appear well preserved. In the cytoplasm, the nucleus (N), hydrogenosomes (H), vesicles (V), axostyle (AX) and costa (C) are observed. Few chromatin masses (CM) could be seen within the nucleus which is surrounded by endoplasmic reticulum (ER) and has a finely granular structure (Fig. A). Invagination of the plasma membrane forming coated vesicles (CV) is observed (Fig. B). Hydrogenosomes present a regular size from 0.3 to $0.5 \mathrm{~mm}$, with a homogeneous matrix and could be seen in close contact with the axostyle. The hollow axostyle traverses the entire body of the parasite, protruding in the form of a spicule at its lower end. The walls of the axostyle consist of longitudinal filaments and its central cavity is filled with a granular mass (Fig. B). The costae have a specific structure resembling that of collagen fibers (Fig. A). Some glycogen granules (black circle) are observed (Fig. A). 


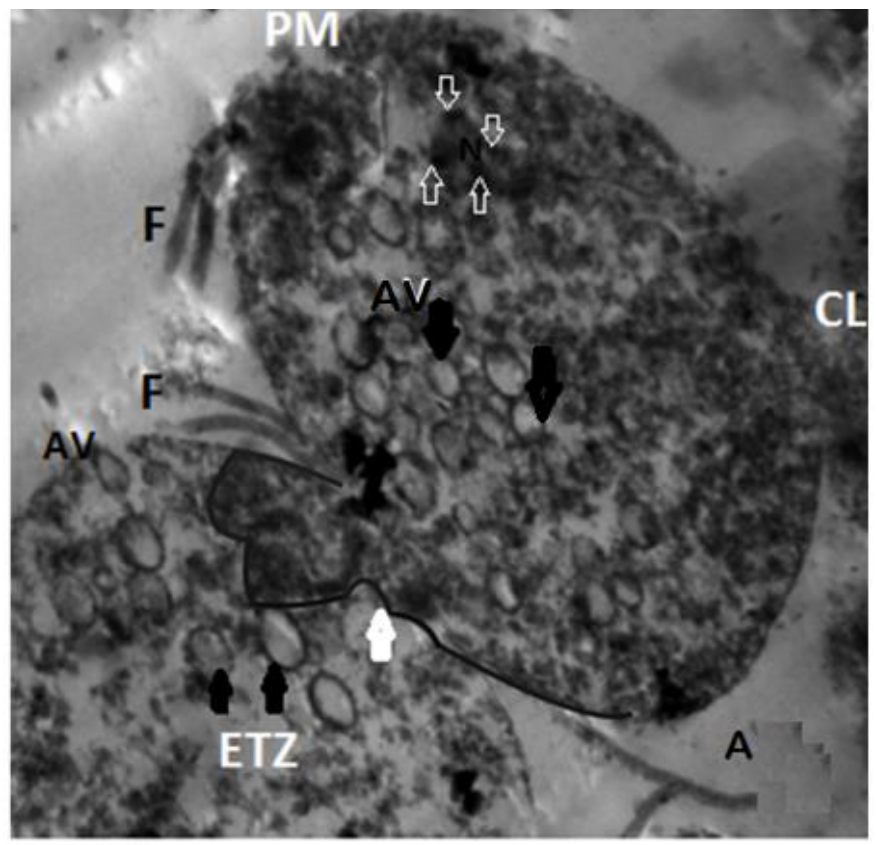

2 microns

TEM Mag $=10000 x$

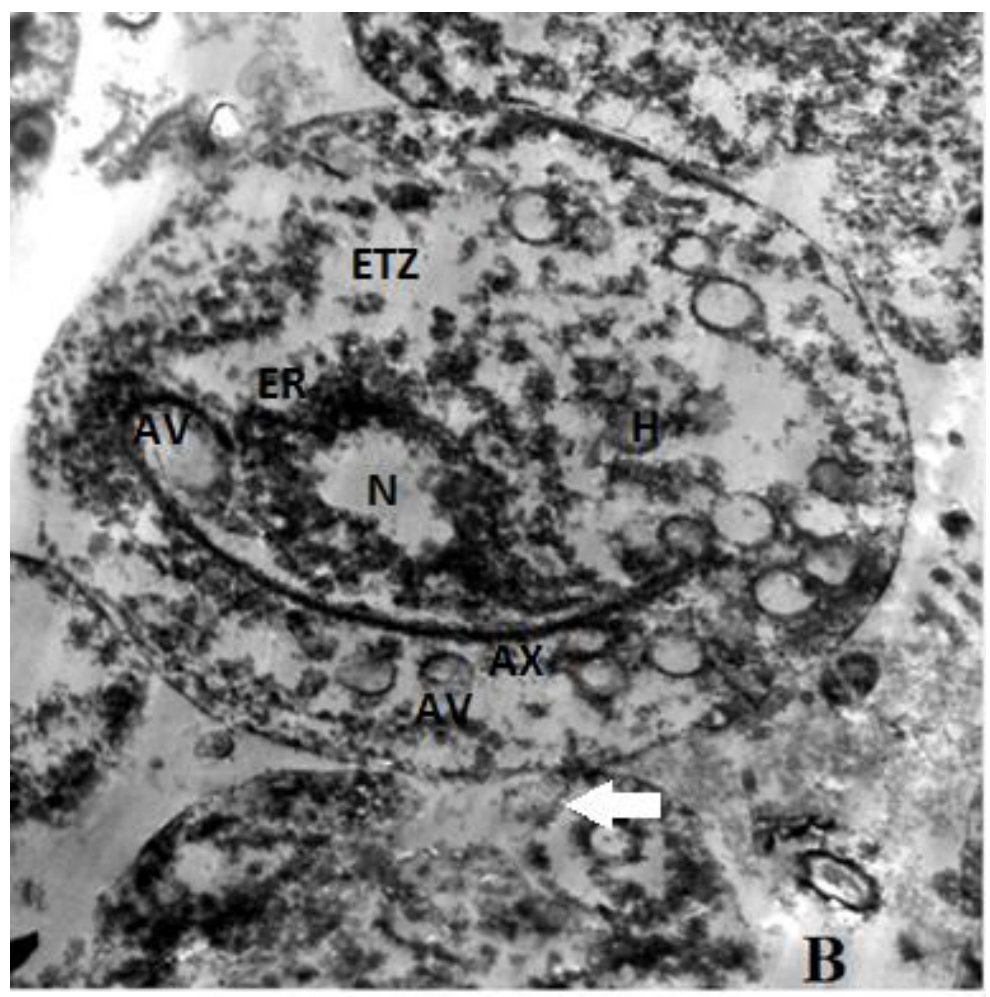

2 microns

MEG Mag $=10000 x$

Fig. (4). Transmission electron micrographs of Liagora farinose treated $T$. vaginalis showing adhesions between trophzoites which is mediated by numerous interdigitating pseudopodia (white compact arrow), damaged Plasma Membrane (PM), Cytoplasmic Leakage (CL), organelles disintegration with appearance of Electron Transleucent Zone (ETZ) (Fig. A), T. vaginalis trophozoites presented rounded Autophagic Vacuoles (AV) with different content (black arrows), some are located at the periphery of the cells and fusing with the plasma membrane, hydrogenosomes (H) are observed and chromatin accumulation inside nucleus (white vacuolated arrows) (Fig. A). Abnormal shape of nucleus (N) with widened Endoplasmic Reticulum (ER) is observed (Fig. B). 


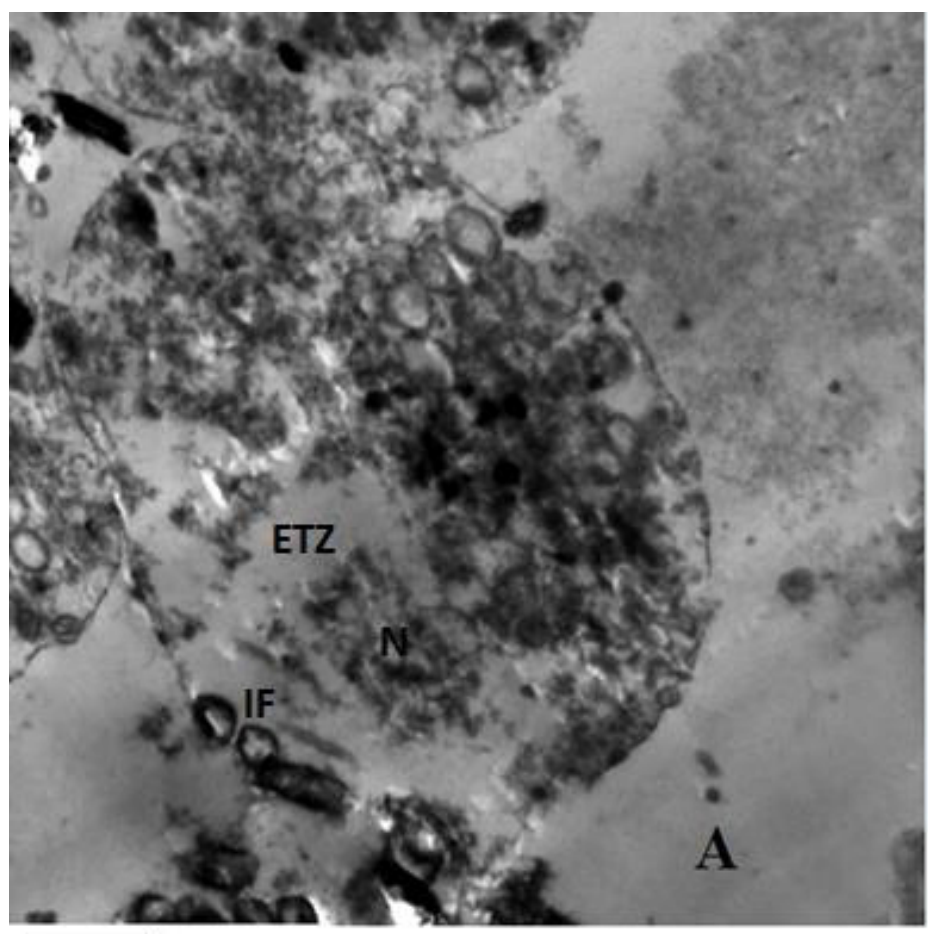

\section{2 microns \\ TEM Mag $=10000 x$}

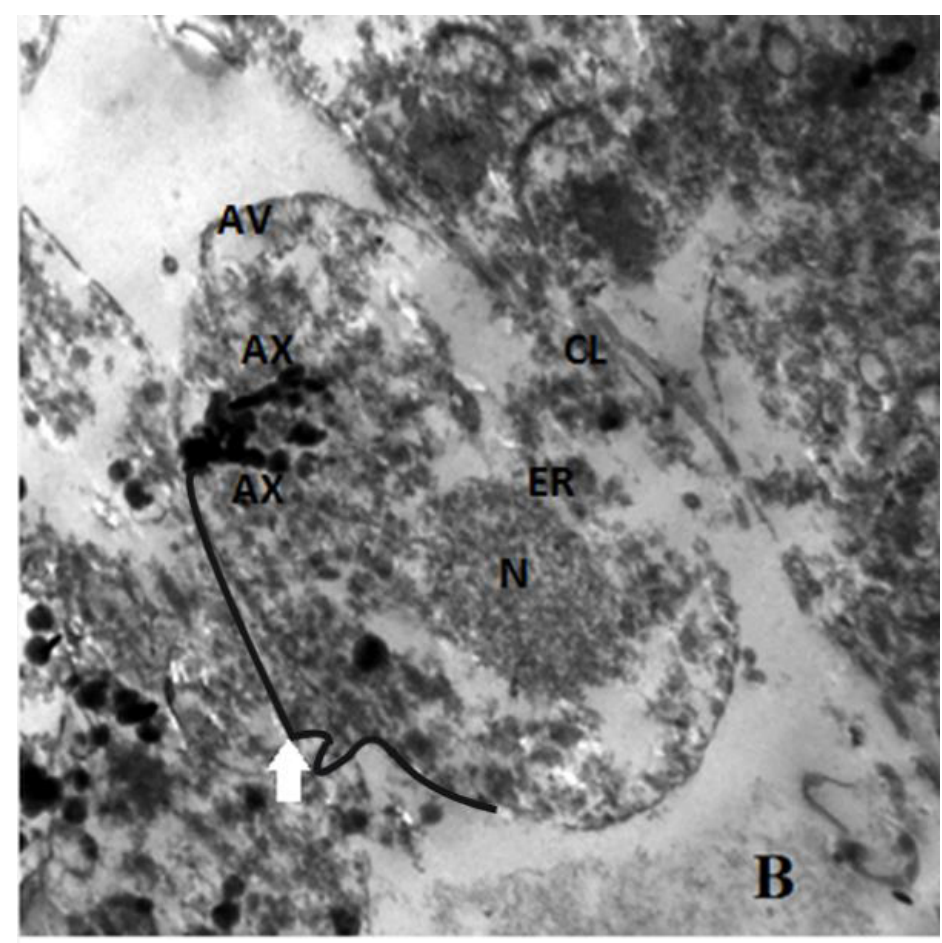

2 microns

TEM Mag $=10000 \mathrm{x}$

Fig. (5). T. vaginalis trophozoites treated with Hydroclarus clathratus showed internalized flagellae (IF) (Fig. A) and multiple axostyles (Fig. B) with intimate contact among cells where cytoplasmic organelle exclusion (white thick arrow) and Autophagic Vacuoles (AV) are observed. Cytoplasmic leakage (CL), organelles disintegration with appearance of Electron Transleucent Zone (ETZ) and widened rough endoplasmic reticulum (ER) (Fig. B). 


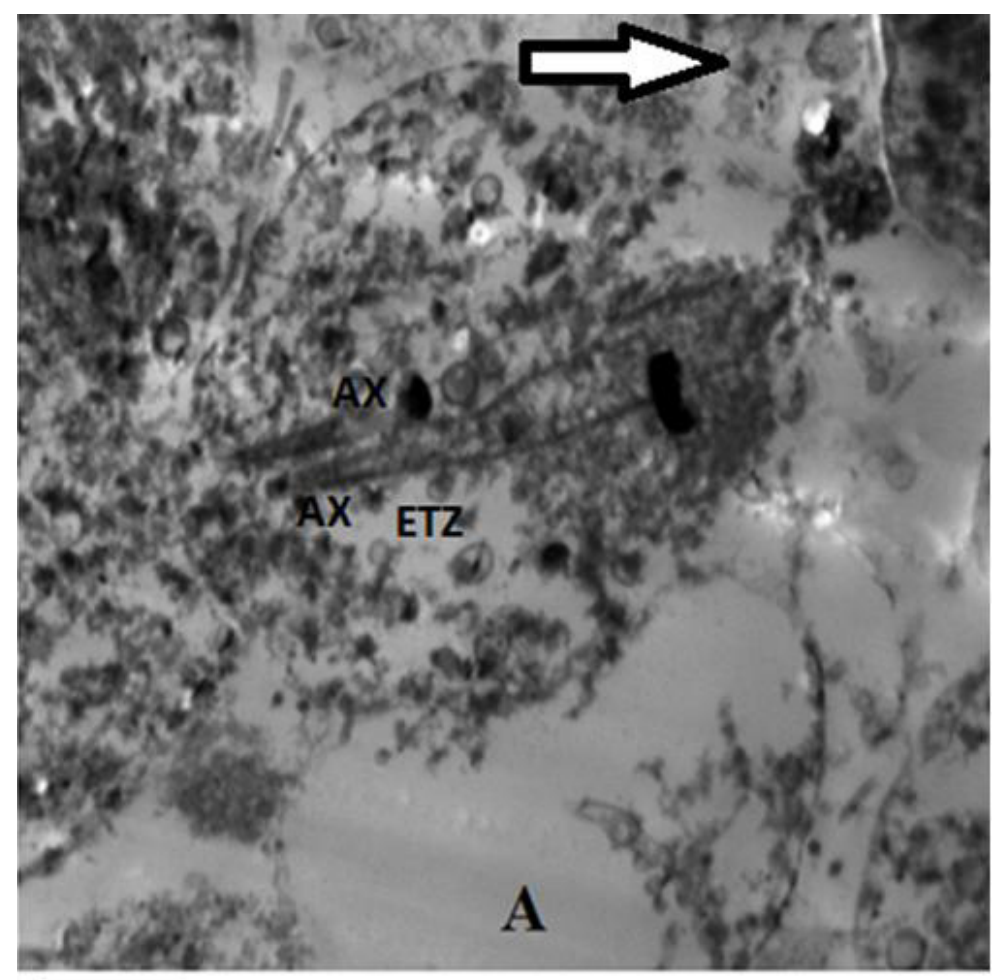

2 microns

TEM Mag $=10000 x$

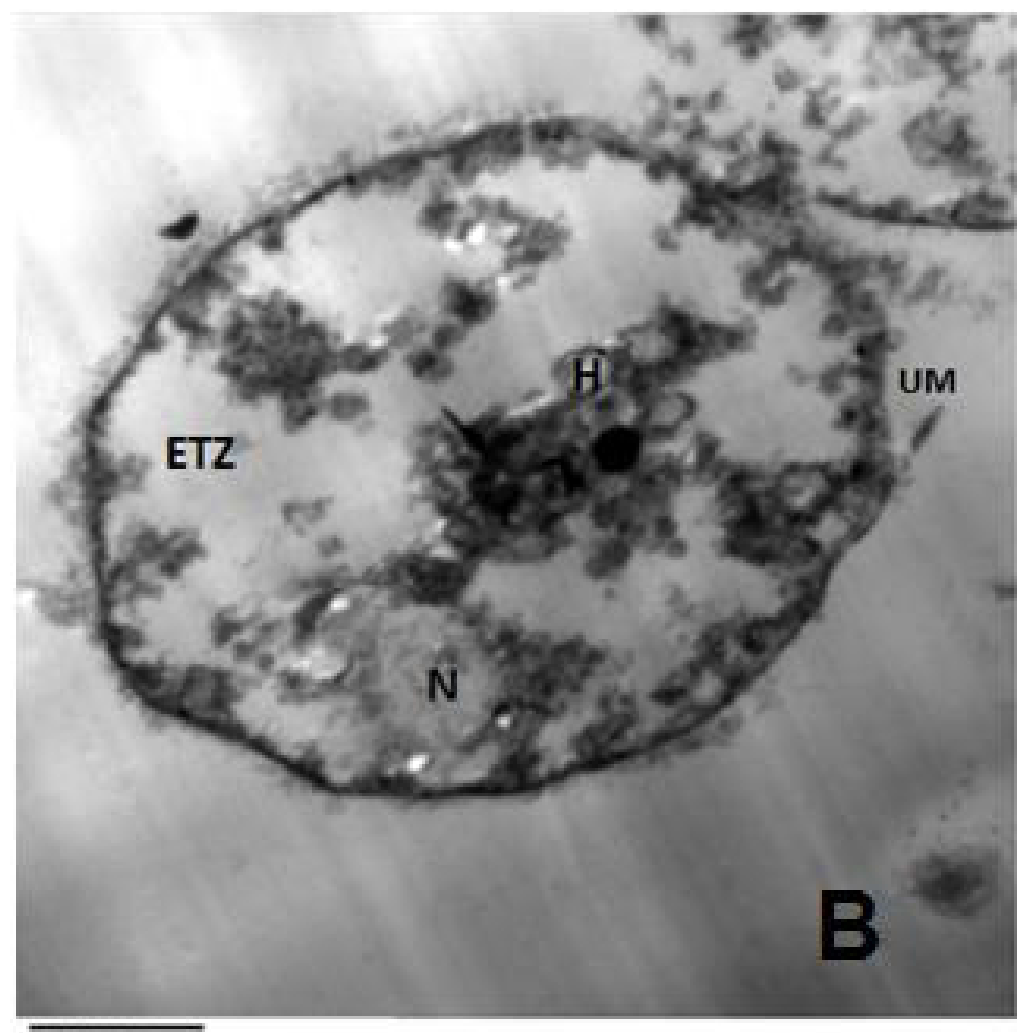

2 microns

TEM Mag $=12000 x$

Fig. $\square$ cont..... 


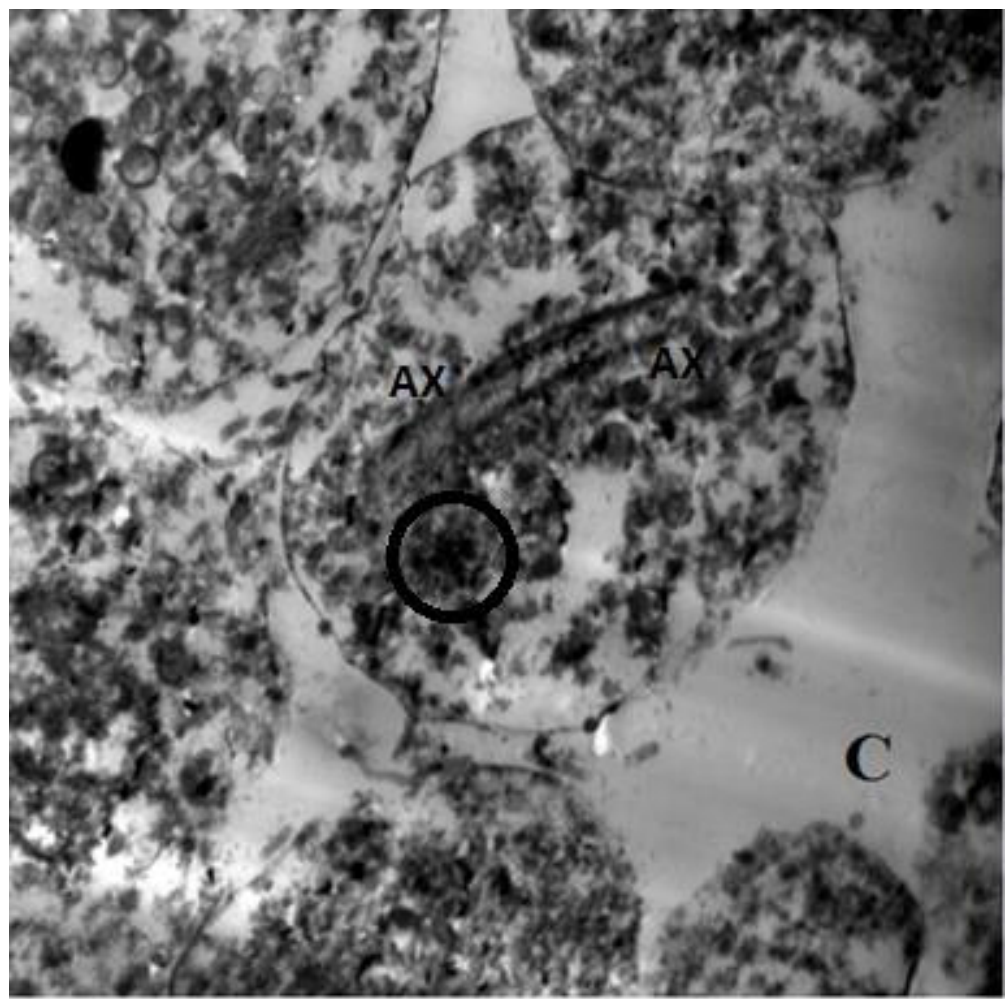

$\overline{2 \text { microns }}$

TEM Mag $=10000 x$

Fig. (6). T. vaginalis trophozoites treated with Holothuria fuscocinerea showing irregular ultrastructure and multiple axostyles (AX) (Figs. A and C) that appear dispersed in the cytoplasm. The content of the parasites was damaged seriously and the cell organelles mostly disappeared with the formation of extensive empty areas in the cytoplasm of the parasite, Electron Transleucent Zone (ETZ) (Figs. A and B) resulting in altered cell architecture. Large amount of glycogen granules (rosettes) (black circle) (Fig. C) are shown. Partially destructed cell membrane is observed. The vacuoles are destructed and hydrogenosomes are decreased in number (Fig. B) compared to untreated trophozoites. Cells showed washed out cytoplasm (white thick arrow in Fig. A).

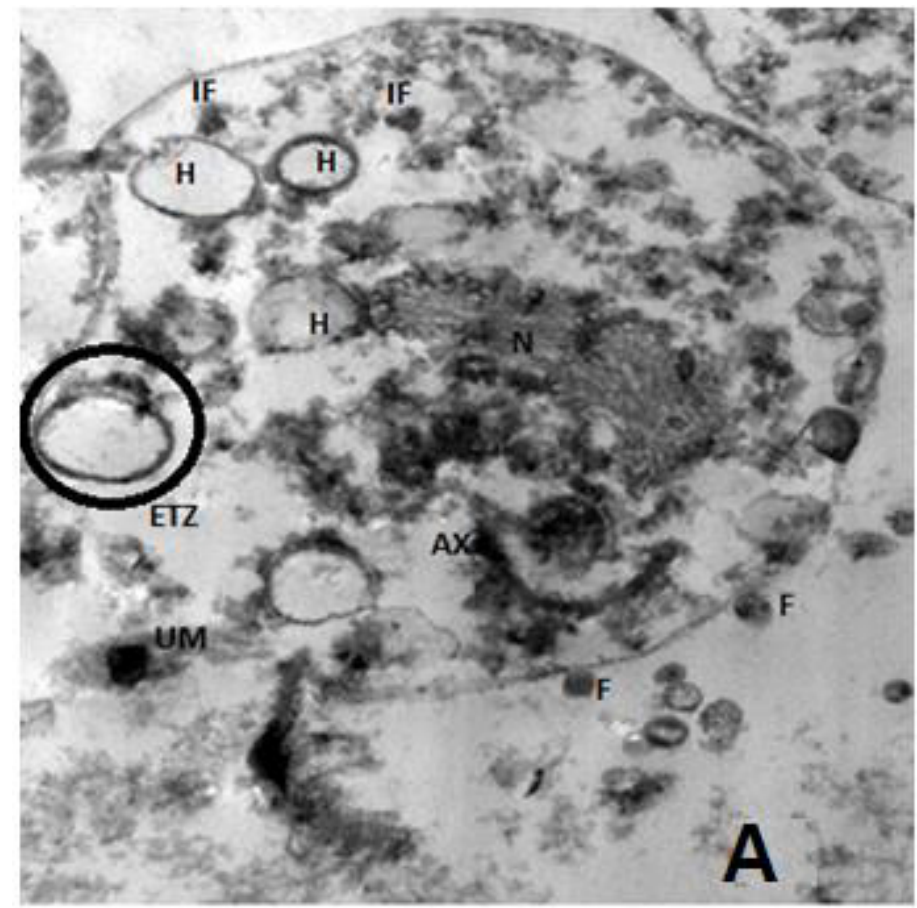

\section{$\overline{500 \mathrm{~nm}}$}

TEM Mag $=20000 x$ 


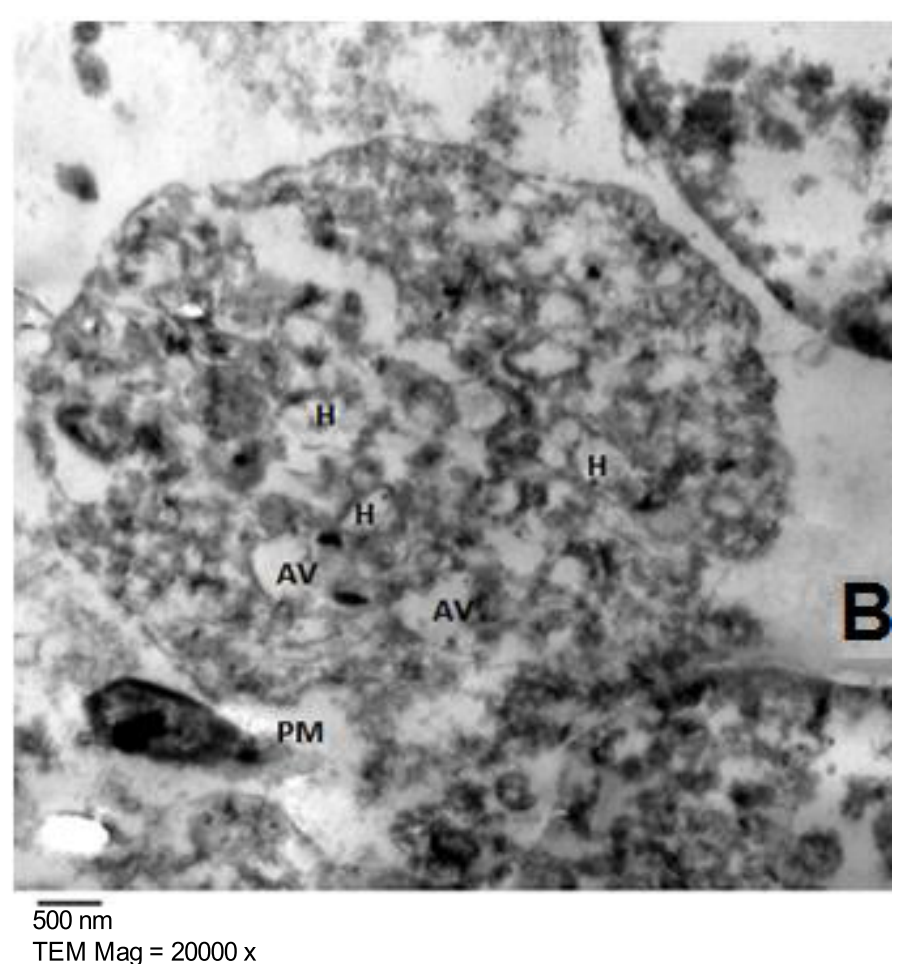

Fig. (7). T. vaginalis trophozoites treated with Echinometra mathaei showed internalized flagella (IF) and externalized flagellea (F) (Fig. A). Its hydrogenosomes are of irregular shape and randomly distributed throughout the cytoplasm with altered matrix (Figs. A and B). A giant hydrogenosome with its altered matrix can be seen (black circle). Distortion of nucleus morphology (Fig. A) and plasma membrane (PM) (Fig. B) are shown. Several vacuoles within the cytoplasm have an autophagic appearance with internal membranes and a digested content that eventually fused with the parasite plasma membrane (PM). Lower cytoplasmic electron density with fragmented axostyle was observed (AX) (Fig. A).

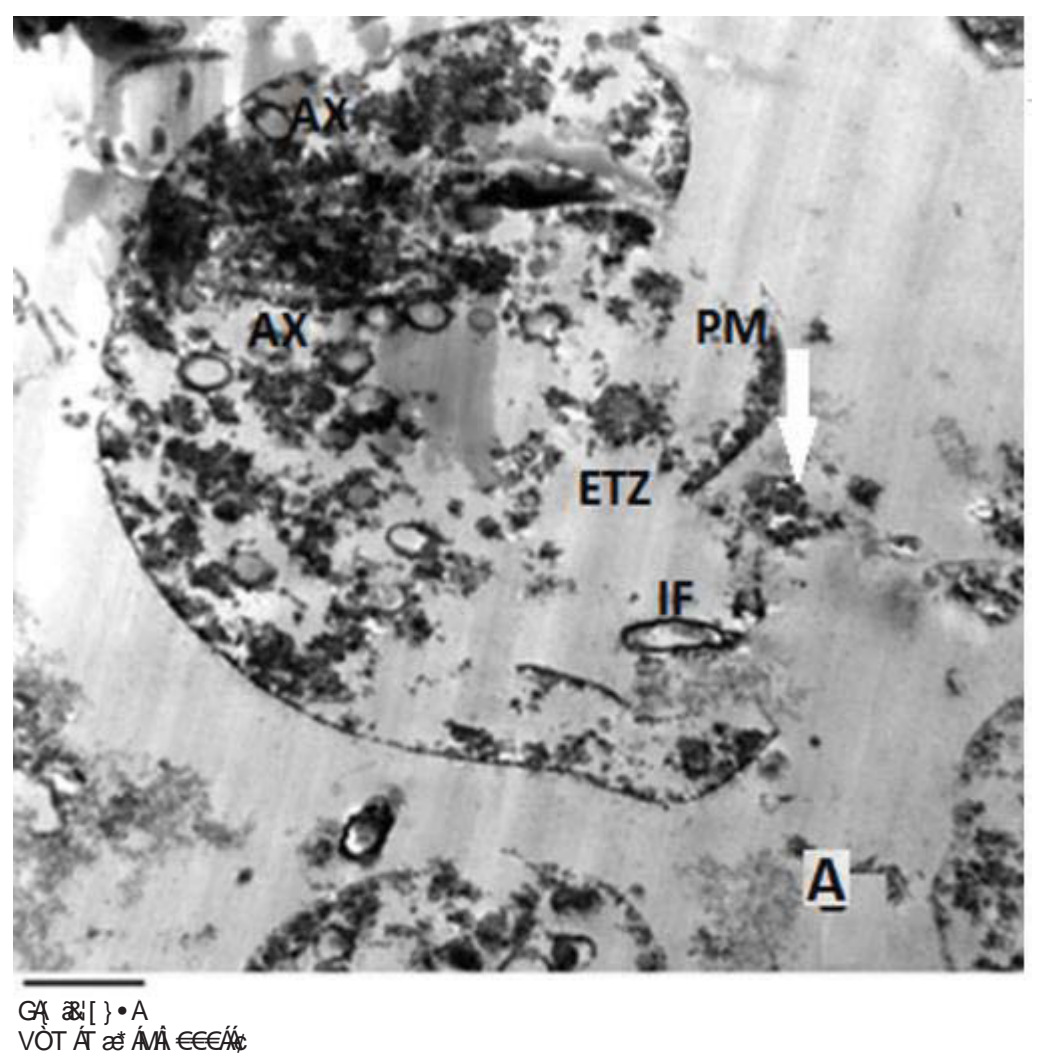

Fig. $\square$ cont..... 

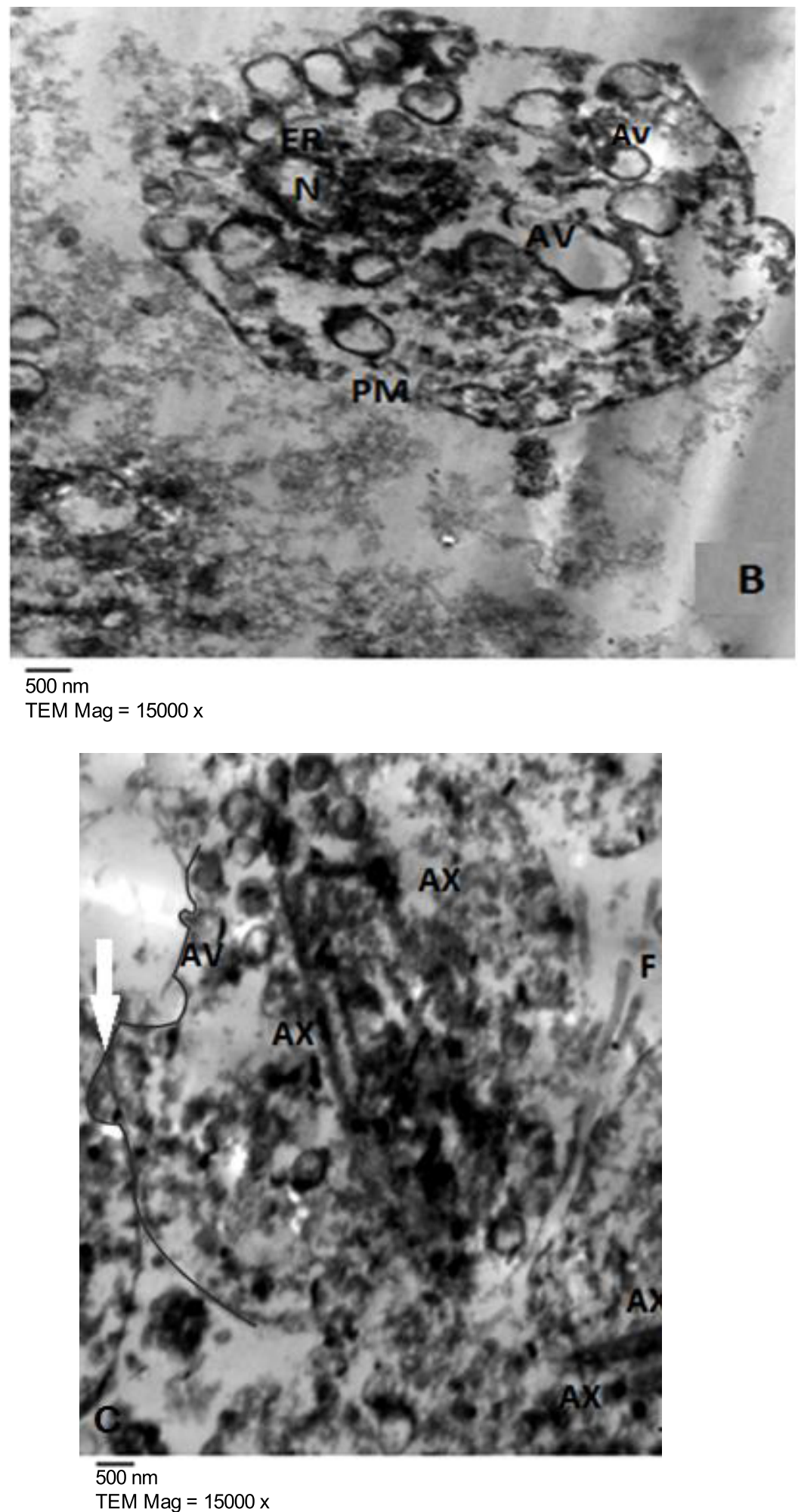

Fig. (8). Transmission electron micrographs of metronidazole $(1 \mu \mathrm{g} / \mathrm{ml})$ showing $T$. vaginalis trophozoites with adhesions mediated by numerous interdigitating pseudopodia (white thick arrow, Fig. C), damaged Plasma Membrane (PM), Cytoplasmic Leakage (thick white arrow, Fig. A), organelles disintegration with appearance of ETZ (A). T. vaginalis trophozoites presented autophagic vacuoles (AV) with different content (Fig. B), some are located at the periphery of the cells and fusing with the plasma membrane (Fig. C). Nucleus is distorted in shape, chromatin is accumulated inside (Fig. B) and endoplasmic reticulum is widened (Fig. B). Internalized flagellae (IF) and multiple axostyles (AX) are seen (Fig. C). 


\section{DISCUSSION}

The initial screening of the anti-T. vaginalis activity of the 8 marine resources revealed that only four were effective in inhibiting parasite growth. None of the four extracts tested were as active as the positive control. However, it is necessary to consider that metronidazole is a pure compound and a reference drug.

From the tested red and brown algae, two species; $H$. clathratus and $L$. farinose, showed high anti-trichomonal activity with IC50; $0.985 \pm 0.08$ and $0.949 \pm 0.04 \mu \mathrm{g} / \mathrm{ml} \pm \mathrm{SD}$, respectively. These results are consistent with previous studies that stated that brown alga Lobophora variegata presented antiprotozoal activities on T. vaginalis, Entamoeba histolytica, Giardia intestinalis, Leishmania mexicana and Trypanosoma cruzi. They approved that the whole extract of L. variegata showed high activity against $T$. vaginalis with IC50, 3.2 $\mu \mathrm{g} / \mathrm{ml} \pm \mathrm{SD}$ and unexpectedly when the whole extract was fractionated, fractions explicated a lower activity [15]. Also, the anti-trichomonal properties of organic algal extracts of 25 tropical seaweeds approved a high to moderate activity from $44 \%$ of the studied seaweeds. Moreover, L. variegata and Udotea conglutinata showed a maximal antiprotozoal activity with IC50 of 1.39 and $1.66 \mu \mathrm{g} / \mathrm{ml} \pm \mathrm{SD}$, respectively [14].

Currently, the methanolic extract of the body wall of Red Sea cucumber $H$. fuscocinerea showed high anti-trichomonal activity with IC50 of $0.798 \pm 0.10 \mu \mathrm{g} / \mathrm{ml} \pm$ SD. Previously, the best antibacterial and antifungal effect of the sea cucumber Stichopus variegatus was shown by the methanolic extract of the body wall in comparison to chloroform and n-hexane extracts [33]. In the same context, the anti-plasmodial capacity of sulfated polysaccharides isolated from the body wall of the sea cucumbers Holothuria grisea and Isostichopus badionotus was recorded [34]. The methanolic extract of the body wall and coelomic fluid of Holothuria leucospilota was shown to exert strong anti-leishmanial activity in experiments with Leishmania infantum tested using both promastigote and axe-nic amastigote forms [35].

In the present study, the methanolic extract of the sea urchin, E. mathaei showed an IC50 $0.845 \pm 0.09 \mu \mathrm{g} / \mathrm{ml} \pm$ SD. Its antibacterial activity has previously been described within a wide range of echinoderm species [36]. The ovary extract of the urchin, Diadema setosum had excellent antimicrobial properties against a vast variety of pathogenic and non-pathogenic bacteria [37]. It has been concluded that the sea urchin, $E$. mathaei, can be a source of novel antibiotics [38].

The ultrastructural alterations viewed here demonstrated the same extent and severity of damage as compared to metronidazole, indicating that they might have the same mechanism of action.

T. vaginalis parasites treated with methanolic extracts from $H$. clathratus, L. farinose, E. mathaei and H. fuscocinerea showed a centripetal relocation of the flagella to the inner (more anaerobic) portions of the cytoplasm. This event may represent an early stress-induced event, prior to cell death of some parasites [39]. It was claimed that $T$. vaginalis, when submitted to stress conditions, internalize their flagella to form pseudocysts as an escape strategy from the environmental changes. Also, it was reported that exposure of $T$. vaginalis to chemicals can lead to pseudocysts formation as an irreversible process that ends up with the cell death, depending on the exposure time and/or the concentration of the chemical employed [40]. The flagella of Tritrichomonas (Tr.) foetus were internalized in an intact and functional form when parasites were submitted to stress conditions, such as variations in the environmental temperature [41]. A similar effect was observed in Giardia lamblia [42] and Tr. foetus [43] trophozoites when incubated with synthetic metronidazole analogs and thiabendazole, respectively. In these studies, trophozoites demonstrated evident ultrastructural disorganization characterized by the internalization of the cytoskeletal components of the flagella and adhesive disc in the cytoplasmic matrix.

In the current study, the marine, as well as the metronidazole-treated parasites, presented an intense cytoplasmic vacuolization with reduced cytoplasmic electron density. Such vacuoles, which varied in size and morphology, exhibited a content resembling membranaceous material. Cytoplasmic vacuolization has been often associated with an autophagic process and cell death [39]. The morphological features of autophagy include cytoplasmic vacuolization, degradation of cytoplasmic ingredients with some chromatin condensation [44]. The autophagic pathway begins with the sequestration of cytoplasm in double-membrane vesicles known as autophagosomes which fuse with lysosomes, and the contents are degraded. One important outcome after treatment against $T r$. foetus with griseofulvin was the presence of vacuolar contents from the flagellae and axostyle-pelta complex, suggesting an autophagic process of odd cellular contents [39]. On the other hand, there is a profuse increasing list of marine drugs reported to inhibit cancer progression through reactive oxygen species (ROS) mediated cell death and autophagy [45]. ROS lead to irreversible oxidative damage to proteins, lipids, and DNA of T. vaginalis trophozoites triggering autophagy. Autophagy comprises processes for cellular homeostasis and cell death [46] and plays an important role in the recycling of ROS and can be considered an effective escape/repair system.

Marine extracts showed a substantial dilatation of endoplasmic reticulum (ER), indicating that the oxidative stress caused by treatment may have interfered in the calcium homeostasis and/or cytochrome activity of the trophozoites. As observed from studies on Leishmania sp., it was stated that some drugs affect the cytoskeleton and can modify the ER [47].

A frequently observed event in both marine extract and metronidazole-treated parasites was the formation of numerous surface interdigitations among adjacent trophozoites, indicating extensive cannibalism associated with necrotic areas and plasma membrane discontinuity. These were frequently observed in T. vaginalis, surviving cells can feed on the nutrients released by dead sibling cells or on attacking the cells per se [48]. Microbial cannibalism was reported in ciliated protozoa and flagellates $[49,50]$.

TEM showed that some of the marine and metronidazoletreated trophozoites drastically changed their morphologies, presenting some multiplicated organelles (axostyles). Several 
authors have observed such abnormal forms when $T$. vaginalis and $T r$. foetus were under drug pressure [39, 51, 52]. Moreover, it was reported that vinca alkaloids produced a reversible block of cytokinesis in Trypanosoma cruzi with the presence of multiple nuclei and kinetoplasts [53].

Accumulation of numerous masses of glycogen was observed in marine extract treated parasites. Parrou et al. (1997) mentioned that glycogen production and accumulation in yeasts can reach up to three times the basal level in response to thermal, hyperosmotic shock or oxidative stress which may be an adaptive mechanism for acquisition of the reserve carbohydrates such as glycogen [54, 55].

Concerning hydrogenosomes, treatment with marine extracts induced a random distribution with the appearance of an irregular matrix, as well as eliciting of a significant increase in volume and decrease in number [56]. The metronidazole is activated to its cytotoxic form in the hydrogenosomes of T. vaginalis and Tr. foetus and the resistant cells had appLR imately one- third the size of hydrogenosomes in comSD rison to the drug-sensitive ones. When hydrogenosomes suffered irreversible damage they underwent an autophagic process and were destroyed [57]. Hydrogenosomes are the key organelles involved in the carbohydrate metabolism of T. vaginalis [58]. Because they are of low redox potentials and the marine extracts are ROS generating drugs [45], it can be considered that the hydrogenosomes observed here might have been partially destroyed due to a direct impact of the marine extracts. They are considered an excellent drug target because their metabolic pathway is distinct from those found in mitochondria, and thus, will probably spare the host cells [57].

Eventually, we presume that the damaged cytoplasmic membrane and organelles might cause Trichomonas trophozoites to die. Similar morphological aspects of $T$. vaginalis treated with pro-apoptotic drugs such as nuclear fragmentation, rounded shape, cytoplasm vacuolation, and apoptoticlike bodies were documented [59]. Moreover, after treatment with different $\mathrm{H}_{2} \mathrm{O}_{2}$ concentrations, rounded shaped Tr. foetus was found with, peripheral masses of chromatin, and elongated hydrogenosomes with an electron-dense matrix, large-sized vacuoles with altered contents, internalized flagellae, ER proliferation, and deformed axostyle [40].

To further understand the exact mechanism of cell death in T. vaginalis, additional molecular studies are necessary. Marine products may contain a defense toxin for its marine organism's body, utilizing these compounds for pharmacological use is conditioned by its toxicity profile that would hinder introducing it for clinical trials if not in safe levels. Further chemical analysis on the present extracts with high antitrichomonal activity would definitely reveal the important chemical and structural components responsible for these biological activities, in view that the potent antimicrobial effect of marine organisms resides in the efficiency of the extraction method [60], and the solvents used [61].

\section{CONCLUSION}

These data suggest that marine extracts from the Red Sea Coast may present potential candidates for further investigation and possible use as anti-trichomonal with regard to their achievability and low cost.

\section{ETHICS APPROVAL AND CONSENT TO PARTICIPATE}

Not applicable.

\section{HUMAN AND ANIMAL RIGHTS}

No animals/humans were used for studies that are the basis of this research.

\section{CONSENT FOR PUBLICATION}

Informed consent was taken from all patients before taking vaginal samples.

\section{CONFLICT OF INTEREST}

The authors declare no conflict of interest, financial or otherwise.

\section{ACKNOWLEDGEMENTS}

Declared None.

\section{REFERENCES}

[1] World Health Organization. Global incidence and prevalence of selected curable sexually transmitted infections: World Health Organization, Department of reproductive health and research. Reprod Health Matters 2012; 20.

[2] Fichorova RN. Impact of $T$. vaginalis infection on innate immune responses and reproductive outcome. J Reprod Immunol 2009; 83(1-2): $185-9$.

[http://dx.doi.org/10.1016/j.jri.2009.08.007] [PMID: 19850356]

[3] Sutcliffe S, Neace C, Magnuson NS, Reeves R, Alderete JF. Trichomonosis, a common curable STI, and prostate carcinogenesis-a proposed molecular mechanism. PLoS Pathog 2012; 8(8): e1002801. [http://dx.doi.org/10.1371/journal.ppat.1002801] [PMID: 22912571]

[4] Muller M, Lindmark DG. Uptake of metronidazole and its effect on viability in trichomonads and Entamoeba invadens under anaerobic and aerobic conditions. Antimicrob Agents Chemother 1976; 9: $696 \mathrm{e} 700$.

[5] Cudmore SL, Delgaty KL, Hayward-McClelland SF, Petrin DP, Garber GE. Treatment of infections caused by metronidazole-resistant Trichomonas vaginalis. Clin Microbiol Rev 2004; 17(4): 783-93. [http://dx.doi.org/10.1128/CMR.17.4.783-793.2004] [PMID: 154893 48]

[6] Schwebke JR, Barrientes FJ. Prevalence of Trichomonas vaginalis isolates with resistance to metronidazole and tinidazole. Antimicrob Agents Chemother 2006; 50(12): 4209-10.

[http://dx.doi.org/10.1128/AAC.00814-06] [PMID: 17000740]

[7] Upcroft P, Upcroft JA. Drug targets and mechanisms of resistance in the anaerobic protozoa. Clin Microbiol Rev 2001; 14(1): 150-64. [http://dx.doi.org/10.1128/CMR.14.1.150-164.2001] [PMID: 111480 07]

[8] Secor WE. Trichomonas vaginalis: Treatment questions and challenges. Expert Rev Anti Infect Ther 2012; 10(2): 107-9. [http://dx.doi.org/10.1586/eri.11.159] [PMID: 22339182]

[9] Imhoff JF, Labes A, Wiese J. Bio-mining the microbial treasures of the ocean: New natural products. Biotechnol Adv 2011; 29(5): 468-82. [http://dx.doi.org/10.1016/j.biotechadv.2011.03.001] [PMID: 214198 36]

[10] Mayer AMS, Rodríguez AD, Taglialatela-Scafati O, Fusetani N. Marine Pharmacology in 2012-2013: Marine compounds with antibacterial, antidiabetic, antifungal, anti-Inflammatory, antiprotozoal, antituberculosis, and antiviral activities; affecting the immune and nervous systems, and other miscellaneous mechanisms of action. Mar Drugs 2017; 15(9): 273.

[http://dx.doi.org/10.3390/md15090273] [PMID: 28850074]

[11] Sabina H, Tasneem S, Sambreen Kausar Y, Choudhary MI, et al. Antileishmanial activity in the crude extract of various seaweed from the coast of Karachi, Pakistan. Pak J Bot 2005; 37: 163-8. 
[12] Orhan E, Esitken A, Ercisli S, et al. Effects of plant growth promoting rhizobacteria (PGPR) on yield, growth and nutrient contents in organically growing raspberry. Sci Hortic (Amsterdam) 2006; 111: $38-43$.

[http://dx.doi.org/10.1016/j.scienta.2006.09.002]

[13] Torres FA, Passalacquaa TG, Velásqueza AM, et al. New drugs with antiprotozoal activity from marine algae. Rev Bras Farmacogn 2014; 24: $265-76$.

[http://dx.doi.org/10.1016/j.bjp.2014.07.001]

[14] Moo-Puc R, Robledo D, Freile-Pelegrin Y. Evaluation of selected tropical seaweeds for in vitro anti-trichomonal activity. J Ethnopharmacol 2008; 120(1): 92-7.

[http://dx.doi.org/10.1016/j.jep.2008.07.035] [PMID: 18725281]

[15] Cantillo-Ciau Z, Moo-Puc R, Quijano L, Freile-Pelegrín Y. The tropical brown alga Lobophora variegata: A source of antiprotozoal compounds. Mar Drugs 2010; 8(4): 1292-304.

[http://dx.doi.org/10.3390/md8041292] [PMID: 20479979]

[16] Machado FLS, Kaiser CR, Costa SS, Gestinari LM, Soares AR. Atividade biológica de metabólitos secundários de algas marinhas do gênero Laurencia. Braz J Pharmacogn 2010; 20: 441-52. [http://dx.doi.org/10.1590/S0102-695X2010000300024]

[17] Scopel M, dos Santos O, Frasson AP, et al. Anti-Trichomonas vaginalis activity of marine-associated fungi from the South Brazilian Coast. Exp Parasitol 2013; 133(2): 211-6. [http://dx.doi.org/10.1016/j.exppara.2012.11.006] [PMID: 23201217]

[18] Edwards DI. Nitroimidazole drugs eaction and resistance mechanisms.Mechanisms of action J Antimicrob Chemother. 1993; 31: p. $9 \mathrm{e} 20$.

[19] Momtaz AS. Soft corals Sarcophyton glaucum as insecticide against Rice weevils Sitophilus oryzae (Coleoptera: Curculionidae). IOSRJESTFT 2016; 10: 10-4.

[20] Hammoda HM, Badr JM, Youssef DT. Three Antioxidant Compounds of the Red Alga Liagora farinose. NPS 2007; 13(2): 140-3.

[21] Boonchum W, Peerapornpisal Y, Kanjanapothi D, Vacharapiyasophon $\mathrm{P}$, et al. Antimicrobial and anti-inflammatory properties of various seaweeds from the Gulf of Thailand. Int J Agric Biol 2011; 13(1): 1560-8530.

[22] Ibraheem IBM, Abd Elaziz BE, Moawad A, Diaz N. Antimicrobial and anti-inflammatory effects of two different marine red algae species collected from Quseir, the Red Sea, Egypt. Asian JCell Biol 2017; 2(223): 1-10.

[http://dx.doi.org/10.9734/AJOB/2017/32964]

[23] Elsayed KN, Radwan MM, Hassan SH, Abdelhameed MS, Ibraheem IB, Ross SA. Phytochemical and biological studies on some Egyptian seaweeds. Nat Prod Commun 2012; 7(9): 1209-10. [PMID: 23074910]

[24] Eltamany EE, Eltahawy NA, Ibrahim AK, et al. Anticancer activities of some organisms from Red Sea, Egypt. Catrina 2014; 9(1): 1-6.

[25] Matloub AA, Awada NE, Khamiss OA. Chemical composition of some Sargassum spp. and their insecticidal evaluation on nucleopolyhedrovirus replication in vitro and in vivo. Egypt Pharmaceut J 2012; 11: 53-8.

[26] Yang R, Johnson MC, Ray B. Novel method to extract large amounts of bacteriocins from lactic acid bacteria. Appl Environ Microbiol 1992; 58(10): 3355-9.

[PMID: 1444369]

[27] Adibpour N, Nasr F, Nematpour F, Shakouri A, Ameri A. Antibacterial and antifungal activity of Holothuria leucospilota isolated from Persian Gulf and Oman Sea. Jundishapur J Microbiol 2014; 7(1): e8708.

[http://dx.doi.org/10.5812/jjm.8708] [PMID: 25147657]

[28] Abubaker L, Mwangi C, Uku J, Ndirangu S. Antibacterial activity of various extracts of the sea urchin Tripneustes gratilla (Echinoidea). Afr J Pharm and Ther 2012; 1(1): 19-23.

[29] Cheesbrough M. Parasitological tests. District laboratory practice in tropical countries Part 1 Cambridge Low Price Editions. Cambridge: Cambridge University Press 1998; pp. 178-310.

[30] Diamond LS. The establishment of various trichomonads of animals and man in axenic cultures. J Parasitol 1957; 43(4): 488-90. [http://dx.doi.org/10.2307/3274682] [PMID: 13463700]

[31] Cedillo-Rivera R, Chávez B, González-Robles A, Tapia A, YépezMulia L. In vitro effect of nitazoxanide against Entamoeba histolytica, Giardia intestinalis and Trichomonas vaginalis trophozoites. J Eukaryot Microbiol 2002; 49(3): 201-8.

[http://dx.doi.org/10.1111/j.1550-7408.2002.tb00523.x] [PMID: 121209 85]

[32] Delmas F, Di Giorgio C, Robin M, et al. In vitro activities of position
2 substitution-bearing 6-nitro- and 6-amino-benzothiazoles and their corresponding anthranilic acid derivatives against Leishmania infantum and Trichomonas vaginalis. Antimicrob Agents Chemother 2002; 46(8): 2588-94

[http://dx.doi.org/10.1128/AAC.46.8.2588-2594.2002] [PMID: 121219 37]

[33] Shakouri A, Shoushizadeh MR, Nematpour F. Antimicrobial activity of sea cucumber (Stichopus variegatus) body wall extract in chabahar Bay, Oman Sea. J Nat Pharm Prod 2017; 12(1): e32422.

[34] Marques J, Vilanova E, Mourão PAS, Fernàndez-Busquets X. Marine organism sulfated polysaccharides exhibiting significant antimalarial activity and inhibition of red blood cell invasion by Plasmodium. Sci Rep 2016; 6: 24368

[http://dx.doi.org/10.1038/srep24368] [PMID: 27071342]

[35] Khademvatan S, Eskandari A, Saki J, Foroutan-Rad M. Cytotoxic Activity of Holothuria leucospilota extract against Leishmania infantum in vitro. Adv Pharmacol Sci. 2016.

[http://dx.doi.org/10.1155/2016/8195381] [PMID: 8195381]

[36] Bryan PJ, Mcclintock JB, Watts SA, Marion KR, Hopkins TS. Antimicrobial activity of ethanolic extracts of echinoderms from the northern Gulf of Mexico. Echinoderms through time. Rotterdam: Balkema 1994; pp. 17-23.

[37] Marimuthu K, Gunaselvam P, Aminur Rahman M, Xavier R, Arockiaraj J, et al. European review for medical and pharmacological sciences antibacterial activity of ovary extract from sea urchin. Diadema setosum 2015; 19: 1895-9.

[38] Kazemi S, Heidari B, Rassa M. Antibacterial and hemolytic effects of aqueous and organic extracts from different tissues of sea urchin Echinometra mathaei on pathogenic streptococci. Int Aquatic Res 2016; 8: 299-308

[http://dx.doi.org/10.1007/s40071-016-0143-0]

[39] Mariante RM, Vancini RG, Benchimol M. Cell death in trichomonads: New insights. Histochem Cell Biol 2006; 125(5): 545-56. [http://dx.doi.org/10.1007/s00418-005-0098-5] [PMID: 16273383]

[40] Mariante RM, Guimarães CA, Linden R, Benchimol M. Hydrogen peroxide induces caspase activation and programmed cell death in the amitochondrial Tritrichomonas foetus. Histochem Cell Biol 2003; 120(2): 129-41.

[http://dx.doi.org/10.1007/s00418-003-0548-x] [PMID: 12844218]

[41] Granger BL, Warwood SJ, Benchimol M, De Souza W. Transient invagination of flagella by Tritrichomonas foetus. Parasitol Res 2000; 86(9): 699-709.

[http://dx.doi.org/10.1007/PL00008555] [PMID: 11002976]

[42] Busatti HG, Alves RJ, Santana-Anjos KG, et al. Effects of metronidazole analogues on Giardia lamblia: Experimental infection and cell organization. Diagn Microbiol Infect Dis 2013; 75(2): 160-4. [http://dx.doi.org/10.1016/j.diagmicrobio.2012.11.001] [PMID: 23331963]

[43] Carvalho KP, Gadelha AP. Effects of three benzimidazoles on growth, general morphology and ultrastructure of Tritrichomonas foetus. FEMS Microbiol Lett 2007; 275(2): 292-300.

[http://dx.doi.org/10.1111/j.1574-6968.2007.00897.x] [PMID: 178250 70]

[44] Fink SL, Cookson BT. Apoptosis, pyroptosis, and necrosis: Mechanistic description of dead and dying eukaryotic cells. Infect Immun 2005; 73(4): 1907-16.

[http://dx.doi.org/10.1128/IAI.73.4.1907-1916.2005] [PMID: 157845 30]

[45] Farooqi AA, Fayyaz S, Hou MF, Li KT, Tang JY, Chang HW. Reactive oxygen species and autophagy modulation in non-marine drugs and marine drugs. Mar Drugs 2014; 12(11): 5408-24. [http://dx.doi.org/10.3390/md12115408] [PMID: 25402829]

[46] Rainey N, Motte L, Aggarwal BB, Petit PX. Curcumin hormesis mediates a cross-talk between autophagy and cell death. Cell Death Dis 2015; 6: e2003.

[http://dx.doi.org/10.1038/cddis.2015.343] [PMID: 26633709]

[47] Jesus JB, Vannier-Santos MA, Britto C, et al. Trichomonas vaginalis virulence against epithelial cells and morphological variability: The comparison between a well-established strain and a fresh isolate. Parasitol Res 2004; 93(5): 369-77.

[http://dx.doi.org/10.1007/s00436-004-1134-4] [PMID: 15205943]

[48] González-Pastor JE, Hobbs EC, Losick R. Cannibalism by sporulating bacteria. Science 2003 ; 301(5632): 510-3. [http://dx.doi.org/10.1126/science.1086462] [PMID: 12817086]

[49] Martinele I, D'agosto M. Predação e canibalismo entre protozoários ciliados (Ciliophora: Entodiniomorphida: Ophryoscolecidae) no rúmen de ovinos (Ovis aries). Rev Bras Zool 2008; 25(3): 451-5. 
[http://dx.doi.org/10.1590/S0101-81752008000300010]

[50] Martel CM, Flynn KJ. Morphological controls on cannibalism in a planktonic marine phagotroph. Protist 2008; 159(1): 41-51 [http://dx.doi.org/10.1016/j.protis.2007.05.003] [PMID: 17768088]

[51] Pereira-Neves A, Ribeiro KC, Benchimol M. Pseudocysts in trichomonads-new insights. Protist 2003; 154(3-4): 313-29. [http://dx.doi.org/10.1078/143446103322454095] [PMID: 14658492]

[52] Madeiro da Costa RF, Benchimol M. The effect of drugs on cell structure of Tritrichomonas foetus. Parasitol Res 2004; 92(2): 159-70. [http://dx.doi.org/10.1007/s00436-003-1023-2] [PMID: 14673646]

[53] Grellier P, Sinou V, Garreau-de Loubresse N, Bylèn E, Boulard Y, Schrével J. Selective and reversible effects of vinca alkaloids on Trypanosoma cruzi epimastigote forms: Blockage of cytokinesis without inhibition of the organelle duplication. Cell Motil Cytoskeleton 1999; 42(1): 36-47.

[http://dx.doi.org/10.1002/(SICI)1097-0169(1999)42:1<36::AID-CM4 $>3.0 . C O ; 2-G]$ [PMID: 9915583]

[54] Parrou JL, Teste MA, François J. Effects of various types of stress on the metabolism of reserve carbohydrates in Saccharomyces cerevisiae: genetic evidence for a stress-induced recycling of glycogen and trehalose. Microbiology 1997; 143(Pt 6): 1891-900.

[http://dx.doi.org/10.1099/00221287-143-6-1891] [PMID: 9202465]

[55] Kanwal S, Saharan RK, Mahmood A, Sharma SC. Effect of reserve carbohydrates on oxidative stress in yeast Saccharomyces cerevisiae
Y6210. CRJBS 2011; 3(6): 633-6.

56] Land KM, Clemens DL, Johnson PJ. Loss of multiple hydrogenosomal proteins associated with organelle metabolism and high-level drug resistance in trichomonads 2001; 97(2): 102-.

[http://dx.doi.org/10.1006/expr.2001.4587]

[57] Benchimol M. The hydrogenosome as a drug target. Curr Pharm Des 2008; 14(9): 872-81

[http://dx.doi.org/10.2174/138161208784041114] [PMID: 18473836]

[58] Embley TM, van der Giezen M, Horner DS, Dyal PL, Foster P. Mitochondria and hydrogenosomes are two forms of the same fundamental organelle. Philos Trans R Soc Lond B Biol Sci 2003; 358(1429): 191-201.

[http://dx.doi.org/10.1098/rstb.2002.1190] [PMID: 12594927]

[59] Chose O, Noël C, Gerbod D, Brenner C, Viscogliosi E, Roseto A. A form of cell death with some features resembling apoptosis in the amitochondrial unicellular organism Trichomonas vaginalis. Exp Cell Res 2002; 276(1): 32-9.

[http://dx.doi.org/10.1006/excr.2002.5496] [PMID: 11978006

[60] Tüney I, Çadirci BH, Ünal D, Sukatar A. Antimicrobial activities of the extracts of marine algae from the Coast of Urla («zmir, Turkey). Turk J Biol 2006; (30): 171-5.

[61] Cox S, Abhu-Ghannam N, Gupta S. An assessment of the antioxidant and antimicrobial activity of six species of edible Irish seaweeds. Int Food Res J 2010; 17: 205-20.

\section{(C) 2019 Tawfeek et al.}

This is an open access article distributed under the terms of the Creative Commons Attribution 4.0 International Public License (CC-BY 4.0), a copy of which is available at: (https://creativecommons.org/licenses/by/4.0/legalcode). This license permits unrestricted use, distribution, and reproduction in any medium, provided the original author and source are credited. 